\title{
The Role of Environment in Improving Learning Quality: A Case Study of Al- Istiqamah Modern Islamic Boarding School
}

\author{
Rara Pratiwi ${ }^{1 *}$ Kamaruddin Kamaruddin ${ }^{2}$, Adawiyah Adawiyah ${ }^{3}$ \\ ${ }^{1}$ Islamic Education Department, Postgraduate, Institut Agama Islam Negeri Palu \\ 2 Islamic Education Department, Postgraduate, Institut Agama Islam Negeri Palu \\ ${ }^{3}$ Islamic Education Department, Postgraduate, Institut Agama Islam Negeri Palu
}

ABSTRACT

This study examines the role of learning environment in improving the quality of learning students in modern boarding school Al-Istiqamah Ngatabaru. Research method used in this research is qualitative method with a case study approach. The data were collected through observation, semistructured interview, and documentary study. Data then analyzed through three stages, namely data reduction, display data and conclusion drawing/verification. The research results show that the role of learning environment in improving the quality of learning cases in modern boarding school AlIstiqamahNgatabaru has a big role so that it affects the achievement of students. Based on the results of research in the field of Islamic boarding school learning environment role is the formation of students through the system pengasramaan, student character formation with the assignment, and the creation of a conducive learning. Supporting learning factors include good classroom, organized learning system, teaching program (TMI), curriculum management, while learning inhibiting factors include teachers demanded for professionals, influences coming from within students and surrounding areas, and inadequate facilities.
ARTICLE

INFORMATION

Keywords:

Design,learning, multicultural, Islamic religious education, schools 


\section{Introduction}

Stimulating, fostering, and increasing students' interest in learning through efforts created by the teacher can be done, including through a good arrangement of the learning environment. Organizing the learning environment is one of the teacher's efforts to create good learning conditions so that the teaching process can take place perfectly. ${ }^{1}$ Learning environments that need to be organized are teacher attitudes, sensory perceptions, motor activities displayed, student seats, teacher table ${ }^{2}$, public tables, light, ventilation, teaching aids, and others. The environment needs to be organized to obtain a stimulating learning atmosphere. Before the teacher's efforts in managing the learning environment foster and stimulate students' interest in learning, students first respond. The response of these students is the result of interactions conducted with particular objects, including the teacher in the learning process. Because however, the teacher's efforts will provide positive stimulus or stimulation.

Likewise, in the teaching and learning process, the environment is a

\footnotetext{
1 Evita, E., Syahid, A., \& Nurdin, N. (2019). Understanding Students' Learning Outcomes Differences Through the Application of the Market Place Activity Type of Cooperative Learning Model and the Application of Conventional Learning Models International Journal of Contemporary Islamic Education, 1(1), 6785.

2 M. Ngalim Purwanto, Ilmu Pendidikan Teoritis Dan Praktis, (Bandung : PT. Remaja Rosda Karya 2006), 77.
}

learning resource that has a lot of influence on the learning process that takes place therein. The environment is one of many factors that influence learning and have an impact on the quality of learning of students. As with learning facilities, the learning environment is one factor that cannot be ignored because the environment is part of humans, especially for students to live and interact with each other.

$$
\text { Sartain (an American }
$$

psychologist) states that "Environment is all-encompassing conditions in this world that in certain ways affect our behavior, growth, development or life processes except for genes."3

Ki Hajar Dewantara classifies the learning environment into three, namely: a) Family environment, b) School environment, c) Community environment. ${ }^{4}$

Ngalim Purwanto stated that "among the factors that influence learning, the environment also influences learning achievement." ${ }^{15} \mathrm{~A}$ supportive learning environment will create a conducive atmosphere that supports students to learn well so that it is expected to facilitate students' success in learning.

Modern Islamic Boarding School, is one of the Islamic educational institutions in Indonesia in its development, underwent various educational system reforms. The early development of the pesantren was seen

3 M. Ngalim Purwanto, Ilmu Pendidikan Teoritis Dan Praktis, (Bandung : PT. Remaja Rosda Karya 2006), 77.

4 Ibid, 101.

5 Ibid, 107. 
when the Dutch colonial government established public schools, so there were reformers who spearheaded the establishment of modern Islamic educational institutions in the early 20th century.

One such Islamic educational institution is Pondok Modern Darussalam Gontor Ponorogo, located in the province of East Java. At that time, pesantren were placed outside the modernization line, and the pesantren students were considered by the public to be smart about religion but blind to general knowledge. Trimurti 7 then adopted a new format and established Pondok Modern Darussalam Gontor by maintaining some of the traditions of the Salaf pesantren. And changing the pesantren teaching methods that use the Watonan (mass) and sorogan (individual) systems to be replaced with classical systems such as public schools, with the following:

$$
\text { الجـديدالأصلة على القــديم الصـالح و الأخذعلى }
$$

Meaning: "Keep the good old kind and do your best"

$$
\text { Modern boarding school }
$$

Darussalam Gontor, founded in 1926, rests based on the pesantren system and institutional base. This boarding house, besides studying religious sciences, also incorporates a number of general subjects into its curriculum. Pondok Modern Darussalam Gontor also encourages its students to study English and Arabic and also carries out a number of extracurricular activities such as sports, arts, and so on. ${ }^{6}$

Modern boarding school Darussalam Gontor Ponorogo already has twenty branch huts, which are thirteen branches of Male Pondok and seven branches of Pondok Putri, scattered in several provinces in Indonesia, ${ }^{7}$ and also alumni huts. One of which the writer will examine is AlIstiqamah Modern Islamic Boarding School Ngatabaru, Sigi Regency, Central Sulawesi, which is one of the Gontor alumni huts.

Efforts to maximize the proportion of religious and general education in Islamic boarding schools have led to efforts to integrate various aspects. This adaptation pattern is a response as well as the existence of changes in the education system in the context of the changing paradigm of educational thought that is developing rapidly both on the theoretical and practical terrain. The development of the pesantren boarding school paradigm can be observed with the breakthroughs made by the boarding school so that there are a variety of new colors that enrich the world of boarding school education. Maybe the audience will be difficult to categorize between classical boarding schools with modern when using the parameters of the development of the times because almost all institutions are competing to

6 Azyumardi Azra, Pendidikan Islam, Tradisi dan Modernisasi di Tengah Tantangan Millenium III, 122-123.

7http://id.wikipedia.org/wiki/Pondok_P esantren Modern Al-IstiqamahNgatabaru(diakses pada tanggal 07Juni 2017).

e-ISSN: 2715-4572

p-ISSN: 2716-1439 


\section{International Journal of Contemporary Islamic Education Vol.2 No. 1 Tahun 2020}

accommodate changes as an institutional strategy in order to survive and be marketable.

Modern Islamic Boarding School Al-Istiqamah Ngatabaru Sigi Regency, Central Sulawesi, is still maintaining its existence in the development of the Islamic boarding school education system, by making updates in improving the system and quality of education. There are two very basic aspects in the development and renewal of the modern Islamic boarding school education system so that it still exists in the midst of the renewal of the education system, including: first, boarding school management and second, learning boarding school.

Here the author will discuss specifically the learning aspects of modern boarding schools. The authors raise the learning problems of modern boarding schools that are inseparable from the learning environment, learning methods, and inhibiting factors and supporters of learning of modern boarding schools themselves.

\section{Literature Review}

\subsection{Concept of Learning Environment}

The environment for humans' is one of the most important elements in their lives because the environment is not only a place for humans to do activities, but the environment is also instrumental in supporting various other activities. In the environment, all the necessities of human life are available, so humans make efforts to exploit their environment for the sake of their livelihood. Therefore, it is very natural that human interaction with the environment will take place continuously and continuously. With this interaction, it is certain that environmental conditions will also be influenced by human behavior. Human attitude and behavior will determine the merits of an environmental condition. Conversely, how humans treat the environment, the impact will affect the quality of human life itself. ${ }^{8}$

The understanding of the environment according to experts include:

1) according to Gustavo, the environment is the total number of conditions that affect the existence, growth, and welfare of an organism on earth. Every element of our lives is part of the environment, including the air we breathe, the condition of our bodies, and every item we consume.

2) According to Chiras, the environment is all factors that biologically affect organisms.

3) According to Shingh, the environment is the interaction of physical systems, biology, and cultural elements that are interconnected in various ways, both individually and together.

4) In Indonesia Law Number 32 the Year 2009 concerning cultural protection, the environment is expressed as a unity of space with all objects, power, circumstances, and living conditions, including humans and their behavior. $^{9}$

From the four boundaries put forward by experts, we can conclude

8 Syukri Hamzah, Pendidikan Lingkungan Sekelumit Wawasan Pengantar, (Bandung: PT. Refika Aditama Cet: I,2013), 1.

9 Ibid, 5. 
that the environment is a source of fulfilling human needs to support their lives and as a breeding ground for all living things, especially humans.

Furthermore, Wasty Soemanto in Erlina Nurmalia put forward the definition of the environment physiologically, psychologically, and socio-culturally as follows:

a. Physiologically, the environment includes all physical conditions and materials in the body, such as nutrition, vitamins, water, acids, temperature, nervous system, blood circulation, breathing, digestion of food, endocrine glands, growth cells, and physical health.

b. Psychologically, the environment includes all stimulation received by individuals from the concession, birth, until death. Stimulation is, for example, in the form of genes, gene interactions, tastes, desires, feelings, goals, interests, needs, volition, emotions, and intellectual capacity.

c. Socio-culturally, the environment includes all stimulation, interaction, and external conditions in relation to the treatment or work of others. Family life patterns, group relationships, community life patterns, training, learning, teaching education, guidance, and counseling are included in this environment. ${ }^{10}$

From this definition, it can be concluded that the learning environment is anything that includes and originates

10 ErlinaNurmalia, Pengaruh Fasilitas dan Lingkungan Belajar TerhadapPrestasi Belajar Siswa Kelas XI IPS MAN MALANG 1.(Malang: Tesis UIN Malang (online) 2010). Diakses dari http:hajs.Pada tanggal 07 juni 2017. from inside and outside of the learners who can support learning activities.

\subsection{Student Learning Environment}

In every side of life, humans are always surrounded by the environment and there is a reciprocal relationship between the two. A learning environment is a place where someone lives, which will indirectly affect the person's condition. On one side of the environment can affect humans, but on the other hand, humans can also affect the environment. It's in line with the opinion of F. Gunawan quoted by Wahyu Jatmika, and The environment is everything around objects that affect each other. The influence of this environment is only a mere influence, and there is no element of responsibility in it. ${ }^{11}$ However, this environment is very influential on a person, whether it is a good or bad environment. Likewise, in the teaching and learning process, the environment is a learning resource that has a lot of influence on the learning process that takes place therein. The environment is also one of the many factors that influence learning and have an impact on student achievement.

Students will interact with the environment during the learning process. The environment provides stimulation to individuals, and vice versa, individuals respond to the environment. In the process of interaction can occur changes in

\footnotetext{
11 Wahyu Jatmika. Hubungan Pengelolaan Proses Belajar Mengajar, FasilitasBelajar, dan Lingkungan Belajar Dengan Motivasi Belajar Kelas III JurusanBangunan STM Wonosari Gunungkidul.(Yogyakarta: Tesis UNY).18 e-ISSN: $2715-4572$ p-ISSN: 2716-1439
} 
behavior in individuals. Changes in behavior that occur can be positive and can also be negative.

When the learning process of students requires a quiet environment, comfortable, away from the noise, and of course, it must support learning. A conducive environment is needed so that students can absorb lessons easily. While the environment that is less conducive will disrupt the learning process so that students will be late and hampered in absorbing lessons.

According to Sartain (an American Psychologist), as quoted by $\mathrm{M}$. Ngalim Purwanto that what is meant by the environment (environment) is a condition in this world that, in certain ways, affects our behavior, growth, development or our Life Processes except for genes. Even genes are also seen as preparing the environment for other genes. ${ }^{12}$

According to Sutari Imam Barnadib "as for the so-called natural surroundings or the environment is something that is around him."13 Meanwhile, according to Zakiyah Daradjat and his friends, in a broad sense, the environment includes climate, shelter, customs, knowledge, education, and nature. In other words, the environment is everything that appears

12 M. Ngalim Purwanto, Ilmu Pendidikan Teoritis Dan Praktis, (Bandung: PT. Remaja Rosda Karya 1995), 72.

13 Sutari Imam Barnadib, Pengantar Ilmu Pendidikan Sistematik, (Yogyakarta: Andi Offset, 1989), 118. and exists in the ever-evolving nature of life. ${ }^{14}$

Thus it can be concluded that the environment is all that appears around us, and there are many factors that influence our development and behavior.

Learning, according to Shalih Abdul Aziz and Abdul Aziz Abdul Majid Learning is a change in students based on experiencing the past, so that true change is created. ${ }^{15}$

According to Arno F. Wittig "Learning is defined as a relatively permanent change an organism's behavioral repertoire occurs as a result of experience." 16 This means learning is a relatively permanent change in behavior that is the result of past experiences or habits.

According to Slameto in the book "Learning and Factors That Influence It" learning is a process of one's effort by someone to obtain a change in new behavior as a whole, as a result of his own experience in interactions with his environment. ${ }^{17}$

Thus it can be concluded that learning is an activity carried out deliberately to cause changes in individuals who are relatively fixed in knowledge (cognitive), relative attitude (affective), and skills (psychomotor).

14 Zakiyah Daradjat, Ilmu Pendidikan Islam, (Jakarta: Bumi Askara, !996), 63.

15 Shalih Abdul aziz, Abdul Aziz Abdul Majid, At-Tarbiyah Wa Thuruqu Tadris, (Mesir: Darul Ma'arif, t.Th), 169.

16 Arno F. Wittig, Psychology Of Learning, (Newyork: Schaum's Autline Series, 1981), 127.

17 Slameto, Belajar dan Faktor-faktor yang Mempengaruhinya, (Jakarta: PT. Rineka Cipta, 1995), 2.

e-ISSN: 2715-4572

p-ISSN: 2716-1439 
After understanding the environment and learning it, it can be concluded that the learning environment of learners is all that appears around students. There are factors that influence their development and behavior in carrying out their activities, namely, efforts to obtain changes in knowledge attitudes and skills. In this case, good learning is expected to arouse students' emotions to be motivated to learn.

\subsection{Learning Environment}

\section{Family}

The family is a related community of life from society and the wider country. ${ }^{18}$ According to Hasan Langgulung, the family is the first unit and the first institution in a society where the relationships that occur in it are mostly direct relations. ${ }^{19}$

In a narrow sense towards a social unit consisting of a husband and wife or in other words, the family is a halal association between a man and a woman who is continuous where one feels at peace with the other in accordance with what is determined by religion and society. ${ }^{20}, 21$

18 Arifin, Hubungan Timbal Balik Pendidikan Agama Di Lingkungan Sekolah dan Keluarga,(Jakarta: Bulan Bintang, 1972), 74.

19 Hasan Langgulung, Manusia dan Pendidikan Suatu Analisa Psikologi Pendidikan, (Jakarta: Alhusna Rizka,1995),346.

20 Ibid.

${ }^{21}$ Rusli, R. (2009). Gagasan Khaled Abu Fadl tentang "Islam Moderat" versus "Islam Puritan" (Perspektif Sosiologi Pengetahuan). Jurnal Ilmiah Ilmu Ushuluddin, 8(1), 99-123.
Considering the importance of such family life, Islam sees the family as of the smallest community of life but more than that. It is an institution of human life that can give the possibility of harm and the happiness of family members in this world and the afterlife.

The family is a natural society where relationships between families are unique. In this environment lies the foundations of education. Here education takes place on its own according to the prevailing social order in it, meaning that it is known and followed by all members of his family. Here it is said the basics of experience through compassion and love, the need for authority, and the values of obedience, precisely because such relationships take place in relationships that are natural personality, the appreciation of them has a very important meaning.

So that the family must get the leadership of the father and mother as the head of the dual who has the responsibility, as well as Islam, Islam instructs both parents to act as family leaders and family protectors. As the Word of Allah Almighty:

Translation:

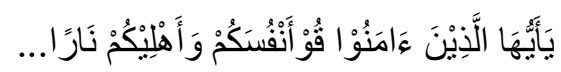

"O you who believe, preserve yourself and your family from the fires of hell ..." (Surah AtTahrim: 6). ${ }^{22}$

22 Departemen Agama RI, MushafAlquran dan Terjemah, (Jakarta: Pustaka Al-Kautsar, 2009), 560. 
From the above paragraph it can be concluded that parents have two functions: parents, family educators and parents as carers and protectors of the family. ${ }^{23}$

With close family relationships, this makes it easy for every parent to instill each family member's attitudes and behavior, especially for their children. Because parents in one family are the first teachers for their children, the role and responsibilities of parents are great and must be carried out to direct and guide their children, so they do not slip and get lost in deviant deeds.

At home, children are accustomed to doing good and knowing bad deeds. The good qualities parents show in their words, and their actions are sought to be imitated by their children. ${ }^{24}$

Broadly speaking, some of the functions of the family in maturing fathers and children are grouped as follows:

1) Protective functions, namely protecting and protecting children from distress and bad influences from outside or inside as well as protecting from the child's inability to get along to adapt to the environment.

2) Biological or procreative functions (procurement), namely all needs that cover all biological needs, including giving birth, caring for and

23 Arifin, Hubungan Timbal Balik Pendidikan Agama Di Lingkungan Sekolah dan Keluarga, (Jakarta: Bulan Bintang, 1972), 75.

24 Zakiyah Dradjat, dkk, Ilmu Pendidikan Islam, cet. Ke-tujuh, (Jakarta: Bumi Aksara,

2008), 72. guaranteeing the health and growth of children.

3) Affective functions include giving affection, warmth, trust, and intimacy, and fostering positive emotions and sentiments towards children and guarding against things that are negative towards the child's self-growth.

4) The recreational function is to present an intimate, warm, friendly, relaxed, and calm and pleasant family climate so that all family members who are at home can feel at home outside the house.

5) Economic functions, namely the provision of income, ensuring the production process and family consumption, and the cost of education for children.

6) The socialist function fosters children at the level of maturity, independence, responsibility, recognition of moral values, and performs the task of living as a creative human being.

7) Educational functions, namely introducing children to legal norms, prohibitions, imperatives, obligations, and norms of civilization as well as being human culture.

8) Religious function in inviting children and all family members to live in a religious atmosphere and have a strong faith. ${ }^{25}$

Students who learn will receive influence from the family in the form of parents' ways of educating, relationships

25 Kartini Kartono, Pengantar Ilmu Pendidikan Teoritis, (Bandung: Mandarmadya, 1992), 115-117.

e-ISSN: 2715-4572

p-ISSN: 2716-1439 
between family members, the atmosphere of the home, family economic situation, understanding of parents, and cultural background. The following factors influence student learning: 26

\section{a) The way parents educate}

The way parents educate their children has a profound effect on their children's learning. Parents who pay less attention to their children's education can cause children to be less successful in their learning. Educating by spoiling is a way of educating that is not good because children will do whatever they want, as well as educating children by violence is a way of educating that is also wrong.

b) Relationships between family members

Relationships between family members that are the most important are the relationship between parents and children. In addition to the child's relationship with his siblings or with other family members, they also influence the way children learn. For the sake of smooth learning and the success of children, good relationships should be sought in the child's family.

c) The atmosphere of the house

Home atmosphere is intended as a situation or event that often occurs in families where children are located and learn. Noisy/crowded home atmosphere will not give peace to children who are learning. Furthermore, so that children

26 Slameto, Belajar dan Faktor-faktor yang Mempengaruhinya, (Jakarta: PT. Rineka Cipta, 2010), 60 . can learn well, it is necessary to create a home atmosphere that is calm and peaceful.

d) State of the family economy

The family's economic situation is closely related to children's learning. Children who are learning need learning facilities. Learning facilities can only be fulfilled if the family has enough money. If a child lives in a low-income family and even has to work to help his family, it can disrupt his learning. Conversely rich families, parents who often have a tendency to pamper children, children only have fun as a result less able to focus their attention on learning.

e) Definition of parents

Learning children need encouragement and understanding from parents. If the child is learning, do not be bothered with chores at home. Sometimes children experience a lack of enthusiasm, and parents are obliged to give understanding and encourage it to help whatever possible difficulties experienced by children in school.

f) Cultural background ${ }^{27}$

The level of education or habits in the family influences the child's attitude in learning. It is necessary for children to inculcate good habits in order to encourage the child's enthusiasm for learning.

\section{School}

School is an important educational institution after the family. The greater the needs of the child, the parents give up their responsibilities as the head of this school institution, the

27 Ibid, . 
school functions as a family aide in educating children. The school provides education and teaches children about education that cannot be, or there is no chance parents provide education and teaching in the family.

The school environment is understood as a formal educational institution, wherein this place teaching and learning activities take place, science is taught and developed by students.

The environment plays an important role in the learning process. Environmental factors that need to be considered in students' learning process are place, learning tools, atmosphere, time, and relationships.

A good place to study is a separate place, the walls are not sharp colors, in the room there is nothing to disturb the attention, and adequate lighting.

a) Tools for learning, the learning process will be disrupted if learning tools are not available, the more complete the learning tools will be, the more people can learn as well as possible. Conversely, if the learning tools are incomplete, the learning process will be disrupted.

b) The atmosphere is closely related to the place of learning. A good learning atmosphere will provide good motivation in the learning process, and this will have a good influence on the quality and student learning achievement. A calm, comfortable, and peaceful atmosphere will support the learning process of students.

c) Time, the right time division will help the learning process of students. The division of time carried out by students can make students learn regularly.

d) Children's relationships will affect children's learning. If children choose to associate with good friends, it will affect the students themselves.

From the definition above, it can be concluded that the School environment is an environment where teaching and learning activities take place that the students are familiarized with the values of the School discipline and the values of learning activities in various fields of study.

School Factors that influence learning include teaching methods, curriculum, teacher relations with students, school discipline, student relations with students, lessons and school time, standard lessons, state of the building, learning methods, and homework assignments. ${ }^{28}$

\section{Public}

Society is taken from the word community. The community can be translated as a local community, which term refers to the residents of a village, city, tribe, or nation. ${ }^{29}$ If members of a group, whether a large group or a small group, live together in such a way that they feel that the group can meet the main interests of life, then the group is called the local community. Society lives

28 Ibid, 64.

29 Nurdin, N. (2018). Institutional Arrangements in E-Government Implementation and Use: A Case Study From Indonesian Local Government. International Journal of Electronic Government Research (IJEGR), 14(2), 44-63. https://doi.org/10.4018/ijegr.2018040104

e-ISSN: 2715-4572

p-ISSN: 2716-1439 


\section{International Journal of Contemporary Islamic Education Vol.2 No. 1 Tahun 2020}

with other colleagues who are in the tribe. From the description above, it can be said that the local community refers to the portion of the community residing in an area (in a geographical sense) with certain boundaries where the main factor on which it is based is greater interaction among its members, compared to outside its boundaries. ${ }^{30}$ Society is a place of association with fellow human beings, a broad field of education, that is, the relationship between two or more infinite people.

The community participates in taking responsibility for education. In a simple society can be interpreted as a collection of individuals and groups bound by the unity of the State, culture, and religion. Every society has certain ideals, regulations, and power systems. ${ }^{31}$ Thus it can be said that in every human activity, it is always influenced by the social environment. And education in society is not a kind of situation in the family. Neither is it a kind of situation of teacher-student relations, but of association with the community. So the community does not educate individuals directly, but in a society where there is an influence in the community itself. ${ }^{32}$

In the context of education, the community environment is an educational institution in addition to the family and school that will shape the habits, knowledge, interests and

30 Seperti yang dikutip Soerjono Soekanto, Sosiologi Suatu Pengantar, (Jakarta: PT Raja Grafindo, 2002), 149.

Pendidikan...,. 44.

31 Zakiyah Daradjat, dkk, Ilmu

32 M. Hafi Ashari, Dasar - dasar Ilmu Jiwa Agama,(Usaha Nasional, Surabaya, 1989), 9. attitudes, morality, community, and children's religion. ${ }^{33}$ Everyone belongs to a family, where he lives among his members in a society and is bound by various social, economic, psychological, and cultural ties. Some interests or relationships are based on cooperation, competition, affection, and even hatred.

\section{Methodology}

This study uses a qualitative approach with the object of research that is Al-Istiqamah Ngatabaru Modern Islamic Boarding School, Sigi Regency, Central Sulawesi.

Use qualitative methods in this study with several considerations. First, adjusting qualitative methods is easier when dealing with multiple realities. Second, it can present the nature of the relationship between researchers and informants. ${ }^{34}$ Third, this method is more sensitive and more adaptable to the many sharpening of shared directors and the patterns of values encountered. ${ }^{35}$

Data were collected using observation techniques, in-depth interviews, and studies from various written documents. ${ }^{36}$ While data analysis was carried out using reduction and verification techniques with various

33

34 Nurdin, N. (2017a). Research in Online Space: The Use of Social Media for Research Setting Jurnal Sistem Informasi (Journal of Information System), 13(1), 67-77.

35 Ibid., 5.

36 Nurdin, N. (2017b). To Research Online or Not to Research Online: Using Internet-Based Research in Islamic Studies Context. Indonesian Journal of Islam and Muslim Societies, 7(1), 31-54. 
data sources. ${ }^{37}$ The reduced data was then analyzed by claiming to the theoretical concepts used in this study.

\section{Result and Discussion}

4.1 The values of the Al-Istiqamah Ngatabaru Modern Islamic boarding school

To realize his ideas, the founder of Al-Istiqamah Ngatabaru Modern Islamic Boarding School, KH. M Arif Siraj, Lc chose the boarding school education boarding with strict discipline based on the philosophical values and orientation that are the basis of the formulation of his vision and mission as described below:

a. Panca Jiwa Pondok Modern AlIstiqamah Ngatabaru

The five souls are values that must be imbued by anyone working in Pondok Modern Al-Istiqamah Ngatabaru, not only santri, but also applies to teachers, clerics, and even kyai families. The five souls are the soul of sincerity, the soul of simplicity, the soul of independence, the soul of ukhuwah islamiyah, and the spirit of freedom that is responsible. The basic values implanted in this boarding house are contained in the five souls of the Islamic Boarding School, which are:

a) Soul of Sincerity

37 Nurdin, N. (2016). The Roles of Information Technology in Islamic Bank Knowledge Management: A study of Two Syariah Banks in Palu. Hunafa: Jurnal Studia Islamika, 13(2),

181-217.

https://doi.org/https://doi.org/10.24239/jsi.v1 3i2.444.181-217
This soul means sepi ing pamrih; that is, doing something not because it is driven by the desire to obtain certain benefits. All work is carried out with the sole intention of worship. So, Kyai is sincere in educating, sincere students are educated, and Kyai is sincere in helping to carry out the educational process.

b) The soul of simplicity

Life in the Islamic boarding school is filled with an atmosphere of simplicity. Simple does not mean positive or nrimo, nor does it mean poor and destitute. Simplicity means, according to needs and obligations. Simplicity contains the values of strength, ability, fortitude, and selfcontrol in the face of life's struggle. Behind this simplicity radiates a great soul, dares to go forward, and never retreats under all circumstances.

c) Self-reliant Soul

Self-reliance or ability to help themselves not only in the sense that students are able to learn and practice taking care of their interests, but the boarding school itself as an educational institution must also be able to be independent so that he does not rely on his survival to the help or mercy of others.

d) Soul of Ukhuwah Islamiyah

Life in boarding schools is filled with close brotherhood; all the ups and downs felt together in the fabric of brotherhood as fellow Muslims. This Ukhuwah not only happened during their study in the hut but also influenced the unity of the Ummah in the community after the students returned home from the Islamic boarding school.

a) Free Soul 
Free in thinking and doing, free in determining the future, free in choosing a way of life, and even free from negative influences from outside, this freedom should not be misused to be too free (liberal) so that it loses direction and purpose of principles. Therefore this freedom must be returned to its purity, which is free within positive lines of discipline with full responsibility, both in the life of the boarding school itself. And also in people's lives. This freedom must always be based on the teachings of true religion. Based on the Al-Kitab and As-Sunnah.

b. Motto Pondok Modern Al-Istiqamah Ngatabaru

Education at the Al-Istiqamah Ngatabaru Modern Islamic Boarding School is directed at the formation of personalities of high-minded, healthyminded, knowledgeable and freethinking Muslim believers. This series of four concepts is called the Pondok Modern Motto.

a) Virtuous minded

High virtue is the foundation that is instilled by the Islamic boarding school to all its students. This is the core of the main objectives of the entire education and teaching process organized by Modern Islamic boarding schools. All activities in the boarding school must contain elements of moral mercy education.

b) Healthy body

Islamic boarding school is a leader cadre institution. A leader must be physically fit, besides of course spiritually healthy, with a healthy body a person is able to carry out his duties, roles and functions well. c) Knowledgeable

The students are equipped with various knowledge to become their life's provisions. Armed with extensive knowledge a person will become wiser in dealing with something. However, it must be kept in mind that knowledgeable knowledge cannot be separated from a noble personality.

d) Free Minded

Free minded, meaning having an open and responsible attitude in facing any problem. But free here is not free as freely as possible without limitations so that it becomes liberal. Freedom is a symbol of maturity and maturity. A santri is free to choose the field of struggle in the community. The application of this free spirit must be based on high intelligence and based on the true teachings of Islam from the AlKitab and As-Sunnah.

\subsection{The Role of the Learning Environment}

Familiarization and parenting systems are one of the strengths of Islamic boarding schools in the parish system and the santri parenting system. Islamic boarding schools that are maximally empowering will provide added value in the formation of students themselves. In addition, of course, the activities and activities of students are easier to control. One of the goals of AlIstiqamah Modern Islamic Boarding School is to prepare high quality and faithful human resources and devote to Allah Almighty. They have extensive knowledge and can actualize it in society. 
Parenting and nurturing systems are businesses, actions or activities organized by Islamic boarding schools in an effective and efficient way to optimize the potential of students to grow and develop fully in various aspects of life both in boarding schools or in the community so that individual students are formed in accordance with the goals of Modern Islamic Boarding School education. Al-Istiqamah Ngatabaru in particular and the aim of national education in general. The institutionalization and nurturing system at Al-Istiqamah Ngatabaru Modern Islamic Boarding School. A model of developing students usually organized and institutionally designed so that all forms of policies in the planning, implementation, supervision, and evaluation stages. Are always formulated institutionally and formally under the responsibility of the daily management Modern Al-Istiqamah Boarding School Ngatabaru.

Guidance for santri through the familiarization and parenting system is to support the attainment of the educational objectives of the AlIstiqamah Ngatabaru Modern Islamic Boarding School in general and to support the success of santri learning in particular. This is in line with the results of the researchers' interview with one of the santri care staff, namely the purpose of fostering santri through the familiarization system, including:

1. Strengthening the intellectual abilities of students in supporting the success of learning.
2. Developing the leadership attitude and organizational ability of students to foster a life together

3. Foster a positive attitude towards students to participate in educational activities and teaching in the educational environment in order to improve the practice of the theory that students have

4. Expanding the students' scientific insights through extracurricular activities

5. Improve students' language skills through extracurricular activities

6. Increase students' art and culture appreciation through extracurricular activities

7. Increasing physical and spiritual freshness of students through extracurricular activities

8. Expanding religious insight, fostering religious attitudes and fostering independence and mentality, increasing religious preaching skills through extracurricular activities

9. Fostering Islamic boarding school education life. ${ }^{38}$

Thus all the activities and activities that exist in the Islamic boarding school environment is coaching and learning for students both in the classroom and outside the classroom.

In the modernization system of the modern Al-Istiqamah Ngatabaru Islamic boarding school in relation to the world of education, it has the same goal, namely one of improving the quality of

38 Habibullah, Staf Pengasuhan Santri. Pondok Pesantren Modern Al-Istiqamah Ngatabaru, Wawancara, pada tanggal 17 Juli 2017.

e-ISSN: $2715-4572$

p-ISSN: 2716-1439 
education. Improving the quality of education is closely related to the learning environment. If the learning environment is conducive, of course, improving the quality of learning achieves good results and impacts the quality of education. In the learning environment, in general, students have a role, according to Ki Hajar Dewantara that there are three aspects included in the category of learning environments, namely family aspects, school aspects, and community aspects. Although in the modern boarding school, Al-Istiqamah Ngatabaru is not directly affected by the touch of aspects of his family and outside the community. However, in the boarding school of modern Al-Istiqamah Ngatabar, the three aspects are integrated.

"... the success of education is inseparable from the three factors that support and support each other, namely school education, family and community education, all of which must receive support from the government. If outside the pesantren environment, this is difficult to realize in an ideal and optimal way. However, the accommodation of these three factors can be integrated. The students live together in dorms that are full of activities and disciplined, under the guidance of the teachers and teachers. ${ }^{39}$

In fostering the nurturing system, of course, parenting has its way of fostering its students, therefore fostering

${ }^{39}$ M. Arif Siraj, Pimpinan Pondok Pesantren Modern Al-Istiqamah Ngatabaru, wawancara, pada tanggal 11 juli 2017. students must have a work program so that when coaching students can be optimal and must be guided by the provisions that have been mutually agreed upon.

The following material fostering the parenting and nurturing system at Al-Istiqamah Ngatabaru Modern Islamic Boarding School includes:

1. Development of students' intellectual abilities related to learning achievement such as joint learning held by the mentor;

2. Fostering students' attitudes and personalities such as time discipline in participating in activities;

3. Fostering scientific insights such as discussions between students;

4. Development of students' abilities and language skills such as memorizing language material (mufradat) and muhadastah between students in foreign languages (Arabic and English);

5. Fostering attitudes, insights, and skills in religion such as muhadharah

6. Fostering appreciation of santri art such as reading the Qur'an with Tartil;

7. Fostering the physical and spiritual freshness of the students, such as getting up at night to pray lail. ${ }^{40}$

The targets and subjects of the fostering of the familiarization and parenting system are all students in which all designs are fully directed to support the improvement of the ability and achievement of students' learning goals. Modern Al-Istiqamah Ngatabaru

40 Dokumentasi Pengasuhan Santri Pondok Pesantern Modern Al-Istiqamah Ngatabaru, 2017.

e-ISSN: 2715-4572

p-ISSN: 2716-1439 


\section{International Journal of Contemporary Islamic Education \\ Vol.2 No. 1 Tahun 2020}

Islamic Boarding Schools in the application of the Islamic education system are required so that all students attending the Islamic School are required to follow the Islamic education system. ${ }^{41}$

Education outside the school that has been running and strived to be developed continuously, both quality and quantity, among others, namely Guidance of reading the Qur'an, basic training in leadership, Student Organization and Cooperatives, Speech Training (muhadharah) in three topics; Arab. English, Indonesian, Scouting Movement, Teaching Practices, Friday and Imam Sermons for students in classes V and VI TMI, Sports, martial arts, zamrah drama, calligraphy, drum band, etc. English courses, Arabic, English, and Arabic debates, sewing, computers, and other activities have become the sunnah and discipline of the modern boarding school Al-Istiqamah Ngatabaru. ${ }^{42}$

The education and teaching management activities in the Islamic boarding school have been scheduled and arranged so that one activity can run well and not collide with other activities.

"... to expect and facilitate the achievement of education and teaching, the Islamic boarding school has implemented several

41 Moh. Wahyudi Pratama, Direktur Pondok Pesantren Modern Al-Istiqamah Ngatabaru. Wawancara, pada tanggal 15 Juni 2017.

42 Dokumentasi Pengasuhan Santri Pondok Pesantern Modern Al-Istiqamah Ngatabaru, 2017. types of activities that are related to each other but are not overlapping so that all time is not independent of daily activities, weekly, monthly, semi-annual and annual activities. ".43

The daily activities of the Boarding school are the activities and activities that students do every day, and each activity is marked with a bell that indicates that the change of activities and all students must immediately rush to do other activities.

Learning is the main activity of education which in its implementation, the Islamic boarding school is given the freedom to choose the strategies, approaches, methods and learning techniques that are most effective in accordance with the characteristics of the students, teachers and the real conditions of the resources available and ready to be used in the boarding school.

The learning process in the modern Al-Istiqamah Ngatabaru boarding school education system is an inseparable part of the Islamic boarding school curriculum itself because it is in the learning process that the curriculum can be transmitted to students. However, a good curriculum is made. Without a learning process or teaching and learning activities, the curriculum is only limited to the concept. For this reason, in a broader understanding of the curriculum, the learning process itself is one aspect of the curriculum content. If the curriculum talks about the

43 Amran Azali, Pengasuhan Santri. Pondok Pesantren Modern Al-Istiqamah Ngatabaru, Wawancara, pada tanggal 17 Juli 2017.

e-ISSN: 2715-4572

p-ISSN: 2716-1439 
objectives and content of learning, the learning process of students so that learning objectives can be achieved. Therein lies the significant relationship between the curriculum and the learning process.

One of the important tasks of the teacher is to make plans and prepare for teaching. This needs to be done so that the effectiveness and efficiency of learning can be achieved. It is very necessary to have a plan so that learning improvements can be achieved. This improvement effort is carried out with the assumption that to improve the quality of learning needs to start with planning. This planning is very important in guiding teachers to carry out their duties as educators in serving the work needs of students.

If the place where students learn is noisy, hot, dark, then the situation will make students lazy and reluctant to learn, because if forced to learn, it will not get optimal results. But if the atmosphere of learning is calm, bright, the friends around him are also in a learning atmosphere, and then this will lead to excitement and motivate learning in students. Therefore someone who wants to succeed in his studies must be able to choose or create the best learning environment and try to leave the environment that is less good for the interests of learning. Thus, a good and appropriate learning environment is thought to improve student learning quality and produce good achievements. As stated by students of the modern boarding school Al-Istiqamah Ngatabaru that:
"Pondok students come from a variety of regions, different habits, and a variety of properties. Surely there are people who make noise with their own friends, bullying, and while others are learning ".44

The conditions and the atmosphere of learning in the class have the same role in improving the quality of learning of students in modern AlIstiqamah Ngatabaru Islamic boarding schools, which can also influence learning interest and learning outcomes so that they will influence the achievements of students. Apart from the atmosphere, there are still many other factors that have an important role in the learning environment at the Islamic boarding school.

The condition of the Islamic boarding school classrooms has been quite good, starting from the air, the arrangement of the room, it's just that there are still classes outside the room due to a large number of students. But some students state that "learning outside the classroom is better than in the room." This is certainly inseparable from the teacher's role in creating enjoyable learning, both from the methods, strategies, and the teacher's disposition.

In the field, researchers found that teachers who were less in control of their lessons will result in their classes a large number of students sleeping during lessons, playing, and

44 Jihan Fadilah, Santriwati kelas V fb TMI Pondok Pesantren Modern Al-Istiqamah Ngatabaru. Wawancara, pada tanggal 28 Juli 2017.

e-ISSN: 2715-4572

p-ISSN: 2716-1439 
memorizing. And also, because of the many activities in the boarding school, there are many students who are tired and sleepy, so they choose to sleep in class. Following is the statement of one of the modern Al-Istiqamah Ngatabaru Islamic boarding school students:

"The number of activities and responsibilities in the boarding house made me reduce my learning concentration, which made me sleepy and forced me to fall asleep while learning took place. Plus, if the teacher who enters is not enthusiastic." 45

Based on the results of research that the learning environment in improving the quality of learning of students in modern boarding school Alistiqamah Ngatabaru has an important role in life in modern boarding schools. Starting from the dormitory environment, school/classroom environment, and social environment (interaction with others).

\section{Conclusions}

Based on the focus of research, exposure to data, as well as a cross-case discussion. The results of this study can be concluded that the role of the learning environment in increasing the quality of student learning in the modern Islamic boarding school AlIstiqamah Ngatabaru has a large role so that it affects the performance of students. Based on the research results in the field, the role of the learning

45 Saidah Ma'rifah, Santriwati kelas akhir TMI Pondok Pesantren Modern Al-Istiqamah Ngatabaru. Wawancara, pada tanggal 28 Juli 2017. environment of the boarding school is Guiding students through the familiarization system, forming the character of students with assignments, and creating conducive learning.

Learning in the modern AlIstiqamah Ngatabaru Islamic boarding school is also the same as other schools, which have inhibited and supported factors in improving the quality of learning. Learning in a boarding school has supporting factors as well as inhibiting factors, namely supporting factors of learning include good classrooms, the learning system is organized, has a teaching program (TMI), curriculum management, while the inhibiting factors of learning include teachers being required to be professional, the influence that comes from within santri and surroundings, and inadequate facilities.

The implication of the learning environment in improving the quality of learning of students in modern Islamic boarding schools Al-istiqamah Ngatabaru is to produce students who excel both in cognitive aspects (knowledge), affective aspects (attitude) and psychomotor aspects (skills).

\section{REFERENCES}

Abdul aziz, Shalih, Abdul Aziz Abdul Majid, At-Tarbiyah Wa Thuruqu Tadris, Mesir : Darul Ma'arif, t.Th.

Amin Silalahi, Gabriel, Metodologi Penelitian Studi Kasus, Sidoarjo: Citramedia, 2003.

Ambarawati, Ni lu Gede. Tingkat Kenyamanan Lingkungan Belajar

e-ISSN: 2715-4572

p-ISSN: 2716-1439 
Sekolah Menengah Atas (SMA), Tesis, 2015.

A.Partanto, Pius \& M. Dahlan Al Barry, Kamus Ilmiah Populer, SurabayaArkola,1994.

Arifin, Hubungan Timbal Balik Pendidikan Agama Di Lingkungan Sekolah dan Keluarga, Jakarta: Bulan Bintang, 1997.

Arifin, Imron, Penelitian Kualitatif dalam Ilmu-ilmu Sosial dan Keagamaan, Malang: Kalimasahada Press, 1996.

Arifin, Zainal,Konsepdan Model Pengembangan Kurikulum: Konsep, Teori, Prinsip, Prosedur, Komponen, Pendekatan,Model, Evaluasi dan Inovasi, Bandung: PT. Remaja Rosdakarya, 2012. ,Penelitian Pendidikan: Metode dan Paradigma Baru, Bandung: PT. Remaja Rosdakarya, 2012.

Arikunto, Suharsimi, Metode Research IIYogyakarta: Andi Offset, 2000.

Ariant, Abaz, Makalah Definisi Kognitif, Afektif dan Psikomotorik, 2012/10. diakses pada tanggal 01 juli 2017.

As Said, Muhammad,Filsafat Pendidikan Islam, Yogyakarta: Mitra Pustaka, 2011.

Aunurrahman, Belajar dan Pembelajaran, Bandung: Alfabeta, 2011.

Azra, Azyumardi, Pendidikan Islam, Tradisi dan Modernisasi di Tengah Tantangan Millenium III, Jakarta: Kencana Prenada Media Group, 2012.

Bungin, Burhan, Analasis Data Penelitian Kualitatif, Jakarta: Raja Grafindo Persada, 2005.
B. Uno, Hamzah, Profesi Kependidikan: Problema, Solusi, dan Reformasi Pendidikan di Indonesia, Jakarta: Bumi Aksara, 2008.

Daradjat, Zakiyah, Ilmu Pendidikan Islam, Jakarta: Bumi Askara, 1996.

Darmadi, Hamid, Kemampuan Dasar Mengajar, Bandung: Alfabeta, 2010.

Departemen Agama RI, MushafAl-quran dan Terjemah, Jakarta: Pustaka AlKautsar, 2009.

Depdiknas, Peningkatan Kualitas Pembelajaran, Jakarta: Depdiknas, 2004.

Djaelani, Aunu Rofiq, Teknik Pengumpulan Data dalam Penelitian Kualitatif, Semarang: Majalah Ilmiah Pawiyatan, 2013.

Dradjat, Zakiyah, dkk, Ilmu Pendidikan Islam, cet. Ke-tujuh, Jakarta: Bumi Aksara, 2008

Djamarah, Syaiful Bahri. Psikologi Belajar. Jakarta: Rineka Cipta, 2008.

Djamarah, Saiful Bahri, Guru Dan Anak Didik Dalam Interaksi Edukatif, Jakarta: Rineka Cipta, 2010.

Ekaputra, H Herman, Variasi Mengajar Guru Dan Aktivitas Belajar Siswa, 2009.

Evita, E., Syahid, A., \& Nurdin, N. (2019). Understanding Students' Learning Outcomes Differences Through the Application of the Market Place Activity Type of Cooperative Learning Model and the Application of Conventional Learning Models International Journal of Contemporary Islamic Education, 1(1), 67-85.

Faisal, Sanafiah, Penelitian Kualitatif: Dasar-Dasar dan Aplikasi, Malang: YA3, 1990. 
F. Wittig, Arno, Psychology Of Learning, Newyork: Schaum's Autline Series, 1981.

Ghazali,M. Bahri,Pesantren Berwawasan Lingkungan, Jakarta: CV. Prasasti, 2004.

Ghofur Abdul. Perbedaan Hasil Belajar Teori Elektronika Antara Siswa Yang Menggunakan Diktat Dengan Siswa Menggunakan Buku Pelajaran, 2011. Diakses dari www.google.com/url. Pada tanggal 08 Juni 2017.

Haedari, Amin dan El-Saha, Ishom, Peningkatan Mutu Terpadu: Pesantren dan Madrasah Diniyah, Jakarta: Diva Pustka, 2004.

Haedari, Amir. at all, Panorama Pesantren Dalam Cakrawala Modern, Jakarta: Diva Pustaka, 2004.

Hamalik, Oemar, Perencanaan Pengajaran Berdasarkan Pendekatan Sistem, Jakarta:BumiAksara, 2003.

Hamalik, Oemar, Proses Belajar Mengajar, Bandung: Bumi Aksara , 2013.

Hamid, Darmadi. Kemampuan Dasar Mengajar, Bandung: Alfabeta. 2010.

Hamzah, Syukri, Pendidikan Lingkungan Sekelumit Wawasan Pengantar, Bandung: PT. Refika Aditama Cet: I, 2013.

Hamzah, Uno Dan Satria Koni, Model Pembelajaran Menciptakan Proses Belajar Mengajar Yang Kreatif Dan Efektif, Jakarta: PT Bumi Aksara, 2007.

Hanafiah, Nanang., Cucu Suhana, Konsep Strategi Pembelajaran, Bandung: Rafika Aditama, 2009.
Hasbullah, Dasar-dasar Ilmu Pendidikan, Jakarta: PT Raja Grafindo Persada, 2008.

http:/ /id.wikipedia.org/wiki/Pondok_ Modern_Darussalam_Gontor diakses pada tanggal 07Juni 2017.

http://uin.ac.id/dspace/.../1/Herry \%2 0kiswantofitk. Diakses 07 Juni 2017.

http:/ / .../lannyjourney.blogspot.com/2 011/05/motivasi-dan-media) pengajaran. Diakses pada tanggal 08 Juni 2017.

Imam Barnadib, Sutari, Pengantar Ilmu Pendidikan Sistematik, Yogyakarta: Andi Offset, 1989.

Jatmika, Wahyu. Hubungan Pengelolaan Proses Belajar Mengajar, Fasilitas Belajar, dan Lingkungan Belajar Dengan Motivasi Belajar Kelas III Jurusan Bangunan STM Wonosari Gunungkidul, Yogyakarta: Tesis UNY, 1996.

Kartono,Kartini. Pengantar Ilmu Pendidikan Teoritis, Bandung: Mandarmadya, 1992.

Koentjaraningrat, Metode-Metode Penelitian Masyarakat, cet. Ke-9, Jakarta: PT. Gramedia, 1989.

Langgulung, Hasan, Manusia dan Pendidikan Suatu Analisa Psikologi Pendidikan, Jakarta: Alhusna Rizka,1995.

L., Ali, Kamus Besar Bahasa Indonesia, Jakarta: Departemen Pendidikan Dan Kebudayaan,1996.

Mardiyah, Kepemimpinan Kiai dalam Memelihara Budaya Organisasi, Malang: Aditya Media Publishing, 2012. 
Moleong, Lexy J., Metodologi Penelitian Kualiltatif Bandung: Remaja Rosdakarya, 2000.

Mudzakir, M. Djauzi, Studi Kasus Desain dan Metode, Jakarta: PT. Grafindo Persada, 1996.

Mulyasa, E. Kurikulum Berbasis Kompetensi, (Bandung: PT. Remaja Rosda Karya, 2004.

Nasution,S. Metode Research (Penelitian Ilmiah), Ususl Tesis, Desain Penelitian, Hipotesis, Validitas, Sampling, Populasi, Observasi, Wawancara, Angket, Jakarta: PT. Bumi Aksara, 2011.

Kualiltatif,
$\begin{aligned} & \text { Rosdodologi } \\ & \text { Bandung: }\end{aligned}$
Remarya, 1998.

Nurdin, N. (2016). The Roles of Information Technology in Islamic Bank Knowledge Management: A study of Two Syariah Banks in Palu. Hunafa: Jurnal Studia Islamika, 13(2), 181217.

https://doi.org/https://doi.org/ 10.24239/jsi.v13i2.444.181-217

Nurdin, N. (2017a). Research in Online Space: The Use of Social Media for Research Setting Jurnal Sistem Informasi (Journal of Information System), 13(1), 67-77.

Nurdin, N. (2017b). To Research Online or Not to Research Online: Using Internet-Based Research in Islamic Studies Context. Indonesian Journal of Islam and Muslim Societies, 7(1), 31-54.

Nurdin, N. (2018). Institutional Arrangements in E-Government Implementation and Use: A Case Study From Indonesian Local
Government. International Journal of Electronic Government Research (IJEGR), 14(2), 44-63. https://doi.org/10.4018/ijegr.201 8040104

Nurmalia, Erlina. Pengaruh Fasilitas dan Lingkungan Belajar Terhadap Prestasi Belajar Siswa Kelas XI IPS MAN MALANG 1. Malang: Tesis UIN Malang (online) 2010. Diakses dari http:hajs. Pada tanggal 07 Juni 2017.

Payudiai, Jurnal Faktor Pendukung dan Penghambat Dalam Pembelajaran, 2011.

Poernomo, Sonjia, Kesehatan Sekolah Di Indonesia, Jakarta: Erlangga, 1990.

Purwanto, M. Ngalim, Ilmu Pendidikan Teoritis Dan Praktis, Bandung: PT. Remaja Rosda Karya 2006.

Purwanto, M. Ngalim. Psikologi Pendidikan. Bandung: Remaja Rosdakarya, 2007.

Pusat Bahasa Departemen Pendidikan Nasional, Kamus Besar Bahasa Indonesia, Edisi Ketiga, Jakarta: Balai Pustaka,2003.

Rohman, Dudung Abdul, Metode Penelitian Sejarah Jakarta: Logos Wacana Ilmu,1999.

Rusli, R. (2009). Gagasan Khaled Abu Fadl tentang "Islam Moderat" versus "Islam Puritan" (Perspektif Sosiologi Pengetahuan). Jurnal Ilmiah Ilmu Ushuluddin, 8(1), 99123.

Saminanto, Ayo Praktik PTK (Penelitian Tindakan Kelas), Semarang: Rasail Media Group, 2010.

Sanafiah,Faisal,Penelitian Kualitatif, Dasar dan Aplikasi, Malang: YA3, 1990. 
Sekretaris, Dokumentasi Pondok Pesantern Modern Al-Istiqamah Ngatabaru, 2017

Sigit, Suhardi, Pengantar Metodologi Penelitian Sosial-Bisnis-Manajemen Bandung: Lukman Offset, 1999.

Slameto, Belajar dan Faktor-faktor yang Mempengaruhinya, Jakarta: PT. Rineka Cipta, 1995.

Sugandi, Achmad, Teori Pembelajaran, Semarang: Universitas Negri Semarang, 2006.

Sugiyono, Memahami Penelitian Kualitatif, Bandung: Alfabeta, 2005. Metode Penelitian Pendidikan, Pendekatan Kuantitatif, Kualitatif, dan RED, Bandung: Alfabeta, 2010.

Metode Penelitian Pendidikan: Pendekatan Kuantitatif, Kualitatif dan $R$ \& $D$ Bandung: Alfabeta, 2007.

Suharsaputra, Uhar. Administrasi Pendidikan, Bandung: Refika Aditama, 2010.

Sukmadinata, Nana Syaodih, Metode Penelitian Pendidikan, Bandung: PT. Remaja Rosdakarya, 2013.

Suprayogo, Imam dan Tobroni, Metodologi Penelitian Sosial-Agama Bandung: PT. Rosda Karya, 2001.

Supri, Hadi, Tesis Pengaruh Lingkungan Belajar Siswa Terhadap Minat Belajar Bidang Studi PAI, 2006.

Suprihatin. Pengaruh Lingkungan Belajar, Minat Belajar, dan Cara Belajar Terhadap Prestasi Belajar Bidang Studi Mekanika Teknik Bangunan Siswa Kelas II SMK 3 Yogyakarta. Yogyakarta. Tesis UNY.
Sunarto, Pengaruh Efektivitas Pembelajaran dan Lingkungan Belajar Siswa terhadap Prestasi Belajar di SMK N 1 Seyegan. Tesis, 2006.

Syah,Muhibbin, Psikologi Pendidikan. Bandung: PT. Remaja Rosda Karya, 2004.

Tim dosen administrasi pendidikan UPI, Manajemen Pendidikan, Bandung: Alfabeta, 2009.

Universitas Islam Indonesia, Al-qur'an dan tafsirnya Jilid VII, Yoqyakarta: Dana Bhakti Wakaf, 1995.

Winata Putra, Udin S, Strategi Belajar Mengajar, Jakarta: Universitas Terbuka, 2007.

Winarno, Bayu. Pengaruh Lingkungan Belajar dan motivasi berprestasi terhadap hasil belajar siswa kompetensi keahlian teknik otomasi industri di SMK N 2 Depok. Depok: Tesis, 2008.

Zuhairini, dkk., Metodologi Pendidikan Agama Jakarta: Ramadhani, 1993. 